Acta vet. scand. $1970,11,181-185$.

From the State Veterinary Research Station for Small Ruminants, Høyland, Sandnes, Norway.

\title{
GENETIC DOMINANT SERUM ALKALINE PHOSPHATASE ACTIVITY IN GOATS
}

\author{
By \\ Torleiv Lode
}

Allcroft \& Folley (1941) observed a wide variation in serum alkaline phosphatase (SAP) activity in healthy cows and sheep. The enzyme activity in the individual animal remained constant for a long period. In young individuals there occurred a gradual decrease until maturity, whereas they recorded a slight rise during pregnancy. The authors further found that the enzyme level of the dairy Shorthorn breed was different from those of other breeds.

A dominantly inherited SAP iso-enzyme in cattle was described by Gahne (1963), and Rendel \& Gahne (1963) showed that the iso-enzyme seems to be associated with the J-blood group system.

In man a similar SAP variation associated with the A-B-Oblood group system was described by Arfors et al. (1963), and forresponding conditions were recorded in sheep (Rendel \& Stormont 1964, Rendel et al. 1964 and Hope 1966).

Genetic relationship between SAP activity and egg production was reported by Hyre et al. (1966), and Law \& Munro (1965) demonstrated the inheritance of SAP variants in fowl plasma.

During investigation on the mineral metabolism in the goat the author observed a SAP pattern which might indicate a genetic influence. Further examinations were carried out and the results to be presented in this paper illustrate this relationship. 


\section{MATERIALS AND METHODS}

The material comprised 290 Norwegian goats in 7 flocks. The animals were from 8 months to $\mathbf{1 0}$ years of age. Most of them were tested only once, but one flock comprising 41 animals was examined by 15 successive samplings during 18 months.

Blood samples were drawn from the jugular vein and the sera were deepfrozen and stored from a few days up to 4 months until examination.

The estimation of SAP activity was performed according to a modified method of Bessey et al. (1946) using "Sigma" reagents. One "Sigma unit" of SAP will liberate $1 \mu \mathrm{mol}$ of nitrophenol per hr. $(1 \mu \mathrm{mol}=0.1391 \mathrm{mg})$. The determinations of high and low SAP activities were done simultaneously by using the same reduced time of reaction. Further, the recommended concentration was exceeded as far as the highest SAP activities were concerned. The maximum observations were 73 units. However, only 8 samples had probably higher values than this limit. The phenotypes are symbolized by $\mathrm{O}$ and $\mathrm{A}$ for low and high levels respectively according to Gahne (1963), and the corresponding genotypes are symbolized $\left(\mathrm{FA}^{\mathrm{A}} / \mathrm{F}^{\mathrm{A}}\right),\left(\mathrm{F}^{\mathrm{A}} / \mathrm{F}^{\mathrm{O}}\right)$ and $\left(\mathrm{F}^{\mathrm{O}} / \mathrm{F}^{\mathrm{O}}\right)$, of which the latter is identical with the $O$ type.

\section{RESULTS}

The SAP activity varied between 0.8 and 73.0 units in the apparently healthy goats. However, the abovementioned 8 samples showed enzyme activities above 73 units. The distribution is

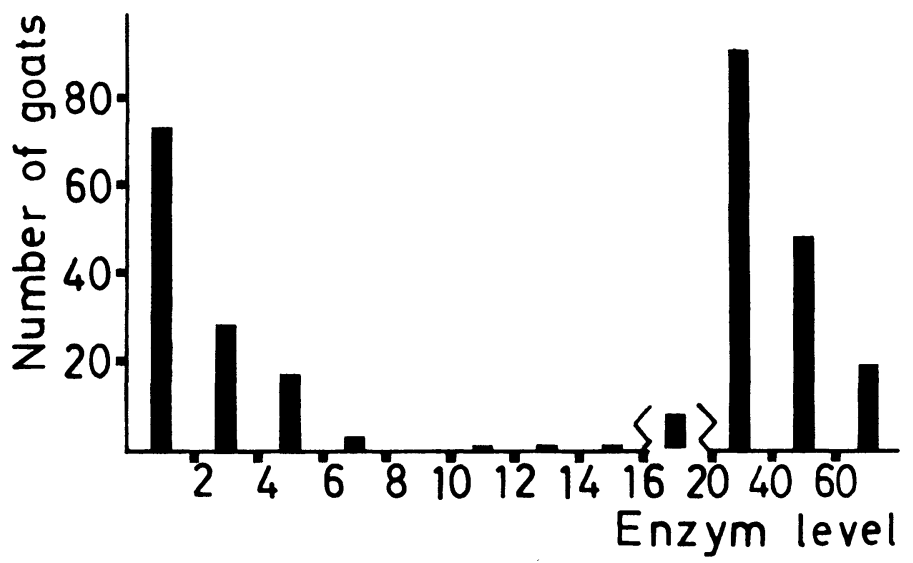

Fig u r e 1. The distribution of individual serum alkaline phosphatase activities in 290 goats. 
T a b l e 1. Segregation of SAP types of 97 offspring having sire of known genotype and dam of known phenotype.

\begin{tabular}{llllllc}
\hline Phenotype & Dam & (A) & Dam & (O) & Genotype & $\begin{array}{c}\text { Number } \\
\text { of sires }\end{array}$ \\
\hline Offspring & (A) & $(\mathrm{O})$ & $(\mathrm{A})$ & $(\mathrm{O})$ & & \\
Observed & 11 & & 10 & & & \\
Excepted & 11 & & 10 & & $\left(\mathrm{FA} / \mathrm{FA}^{\mathrm{A}}\right)$ & 1 \\
Observed & 12 & 7 & 17 & 13 & $\left(\mathrm{FA} / \mathrm{F}^{0}\right)$ & 3 \\
Expected & 14.89 & 4.11 & 15 & 15 & & \\
Observed & 6 & 5 & $1^{\star}$ & 16 & & \\
Excepted & 6.25 & 4.75 & 0 & 17 & $\left(\mathrm{~F} 0 / \mathrm{F}^{\circ}\right)$ & 3 \\
\hline
\end{tabular}

* error.

The sum of 3 chi-squares with 6 degrees of freedom is 4.51. This value is between the $50 \%$ point (5.35) and $75 \%$ point (3.75).

illustrated in Fig. 1 where two distinct peaks are conspicuous. The limit between the low (type $O$ ) and the high activity (type A) seemed to be at about $\mathbf{1 0}$ units. The means and standard deviations of the two types were $2.37 \pm 1.42$ and $37.73 \pm 14.78$ units respectively.

In the flock examined by 15 successive samplings no lappingover between the $O$ and the $A$ group occurred. By two-way analysis of variance both groups showed highly significant variation with regard to time and animal. The "type O" SAP levels were significantly higher (4.11 units) in younger goats ( 8 to 30 months of age) than in older ones (1.80 units). There was no effect of age in type $A$ animals. Both the type $A$ and the type $O$ mean values showed significant differences between flocks.

Segregation is illustrated in Table 1 showing the SAP types of 97 offspring having sire of known genotype and dam of known phenotype. The genotypes of the sires are classified according to the segregation. The dams have been divided into hypothetic genotypes by the equations:

$$
\begin{aligned}
& \mathrm{p}^{2}+2 \mathrm{pq}+\mathrm{q}^{2}=1 \text { and } \mathrm{p}+\mathrm{q}=1 \\
& \mathrm{p}^{2}=\text { frequency of }\left(\mathrm{F}^{0} / \mathrm{F}^{0}\right)=0.582,2 \mathrm{pg}=\left(\mathrm{F}^{\mathrm{A}} / \mathrm{F}^{0}\right)=0.361 \text { and } \\
& \mathrm{q}^{2}=\left(\mathrm{FA}^{\mathrm{A}} / \mathrm{F}^{\mathrm{A}}\right)=0.057
\end{aligned}
$$

\section{DISCUSSION}

From the method described it appears that exact determinations for enzyme activity did not exceed 73 units. However, as 
values above this limit could be classified as high, the method should be well fitted for the purpose.

As can be seen from Fig. 1 the individual values constituted two distinct peaks, highly different from a normal distribution. It should be mentioned that the peak illustrating the $O$ type should have been more distinct if the values were corrected for age, as younger individuals revealed a significantly higher SAP level than the older. For example, before the kids were 6 months of age their SAP level was impossible to classify (Lode 1969).

It is remarkable that the one sire classified into the genotype ( $\left.F^{A} / F^{A}\right)$ had a higher SAP level than sires belonging to the genotype $\left(\mathrm{FA}^{\mathrm{A}} / \mathrm{F}^{\mathrm{O}}\right)$.

One offspring showed a high SAP level though both individuals recorded as parents belonged to the $O$ type. The explanation of this discrepancy may be that the parentage quoted was wrong.

\section{REFERENCES}

Allcroft, W. M. \& S. J. Folley: Observations on the serum phosphatase of cattle and sheep. Biochem. J. 1941, 35, 254-266.

Arfors, K. E., L. Beckman \& L. G. Lundin: Genetic variations of human serum phosphatases. Acta genet. (Basel) 1963, 13, 89-94.

Bessey, O. A., O. H. Lowry \& M. J. Brock: A method for the rapid determinations of alkaline phosphatase with five cubic millimeters of serum. J. biol. Chem. 1946, 164, 321-329.

Gahne, B.: Genetic variation of phosphatase in cattle serum. Nature (Lond.) 1963, 199, 305.

Hope, R. M.: Association between serum alkaline phosphatase variants and the R-O-I blood group system in the Australian Merino. Aust. J. biol. Sci. 1966, 19, 1171-1178.

Hyre, H. M., W. G. Martin, M. R. McClung \& H. Patrick: Genetic relationship between serum alkaline phosphatase and egg production. Poult. Sci. 1966, 45, 1094.

Law, G. R. J. \& S. S. Munro: Inheritance of two alkaline phosphatase variants in fowl plasma. Science 1965, 149, 1518.

Lode, T.: 1969, unpublished.

Rendel, J. \& B. Gahne: Interaction between phosphatases and the J blood groups in cattle. Immunogenetics Letter 1963, 3, 38-41.

Rendel, J., O. Aalund, R. A. Freedland \& F. Mфller: The relationship between the alkaline phosphatase polymorphism and blood group $O$ in sheep. Genetics 1964, 50, 973-986.

Rendel, J. \& C. Stormont: Variants of ovine alkaline serum phosphatases and their association with the R-O blood groups. Proc. Soc. exp. Biol. (N.Y.) 1964, 115, 853-856. 


\section{SUMMARY}

Serum alkaline phosphatase activity was determined in 290 Norwegian goats, from 8 months to 10 years of age. The investigations revealed a wide range of individual enzyme activities which constituted two distinct peaks with mean values of $2.37 \pm 1.42$ and 37.73 \pm 14.78 "Sigma" units per $\mathrm{ml}$ respectively. Forty-one of the 290 goats were examined by 15 successive samplings for 18 months without obtaining lapping-over values between the two groups. The segregation of the high enzyme level indicated a genetic dominant inheritance.

\section{SAMMENDRAG}

Arvelig dominant alkalisk fosfatase aktivitet $i$ serum hos geit.

Alkalisk fosfatase aktivitet i serum ble bestemt hos 290 norske geiter i alderen fra 8 måneder til 10 år. Unders $\varnothing$ kelsene avsl $\varnothing$ rte en stor spredning av individuell enzymaktivitet. Det var to tydelige topper konsentrert $\mathrm{i}$ områdene omkring middelverdiene 2,37 og 37,73 "Sigma" enheter, med standardavvik på henholdsvis 1,42 og 14,78 enheter. Hos 41 av geitene ble det foretatt 15 enzymbestemmelser fordelt over et tidsrom pá 18 måneder. Unders $\varnothing$ kelsene tyder bestemt på at h $\emptyset \mathrm{g}$ alkalisk fosfatase aktivitet $\mathrm{i}$ serum hos geit nedarves med enkel dominans.

(Received August 28, 1969). 